\title{
Effect of Buttermilk Made from Creams with Different Heat Treatment Histories on Properties of Rennet Gels and Model Cheeses
}

\author{
P. Morin, ${ }^{*}$ Y. Pouliot, $†$ and M. Britten*1 \\ *Food Research and Development Centre (FRDC), Agriculture and Agri-Food Canada, 3600 Casavant Boulevard West, St-Hyacinthe, \\ Quebec, J2S 8E3 Canada \\ †STELA Dairy Research Group, Institute for Nutraceuticals and Functional Foods (INAF), Université Laval, Quebec City, \\ Quebec, G1K 7P4 Canada
}

\section{ABSTRACT}

Although many studies have reported negative effects on cheese properties resulting from the use of buttermilk in cheese milk, the cause of these effects has not been determined. In this study, buttermilk was manufactured from raw cream and pasteurized cream, as well as from a cream derived from pasteurized whole milk. Skim milks with the same heat treatments were also manufactured to be used as controls. Compositional analysis of the buttermilks revealed a $\mathrm{pH}$ 4.6insoluble protein content approximately $10 \%$ lower than that of the skim milk counterparts. Milk fat globule membrane (MFGM) proteins remained soluble at $\mathrm{pH} 4.6$ in raw cream buttermilk; however, when heat was applied to cream or whole milk before butter making, MFGM proteins precipitated with the caseins. Rennet gel characterization showed that MFGM material in the buttermilks decreased the firmness and increased the set-to-cut time of rennet gels, but this effect was amplified when pasteurized cream buttermilk was added to cheese milk. The microstructure of gels was studied, and it was observed that gel appearance was very different when pasteurized cream buttermilk was used, as opposed to raw cream buttermilk. Model cheeses manufactured with buttermilks tended to have a higher moisture content than cheeses made with skim milks, explaining the higher yields obtained with buttermilk. Superior retention of MFGM particles was observed in model cheeses made from pasteurized cream buttermilk compared with raw cream buttermilk. The results from this study show that pasteurization of cream and of whole milk modifies the surface of MFGM particles, and this may explain why buttermilk has poor coagulation properties and therefore yields rennet gels with texture defects.

Received August 31, 2007.

Accepted November 26, 2007.

${ }^{1}$ Corresponding author: brittenm@agr.gc.ca
Key words: buttermilk, rennet gel, milk fat globule membrane, cheese

\section{INTRODUCTION}

In 2005 , butter production totaled $6.1 \times 10^{8} \mathrm{~kg}$ and $8.4 \times 10^{7} \mathrm{~kg}$ in the United States (USDA, 2006) and Canada (Statistics Canada, 2007), respectively. Most plants produce butter from $40 \%$ milk fat containing pasteurized cream. Churning of $40 \%$ milk fat cream yields almost equal amounts of butter and buttermilk. Buttermilk contains most of the aqueous soluble components, including a portion of the shredded milk fat globule membranes (MFGM). Considering the rather large volumes of buttermilk produced, this low-value byproduct is either condensed or spray-dried to ensure longer shelf life. Because of its poor oxidative stability (O'Connell and Fox, 2000) and its nutritional similarity to skim milk powder, buttermilk powder is often used for animal nutrition. A number of applications have been developed for buttermilk, including bakery products, dry mixes, and dairy products; however, the functional properties of buttermilk often equal or are inferior to those of skim milk or whey powder (Wong and Kitts, 2003). Because of the compositional similarities between buttermilk and skim milk, research has been carried out on the potential for using buttermilk in cheese milk (Mistry et al., 1996; Poduval and Mistry, 1999; Raval and Mistry, 1999; Turcot et al., 2001; Govindasamy-Lucey et al., 2006, 2007). Given the CN content of buttermilk, this substrate could potentially be exploited to improve the economics of cheese manufacturing. Although substituting buttermilk in cheese milk in very small amounts (5 to 10\%) appears to minimize any adverse effects, adding larger amounts creates curds with texture defects and high moisture (Joshi et al., 1994).

The use of UF or condensed buttermilk in cheese milk has also been reported (Poduval and Mistry, 1999; Raval and Mistry, 1999; Govindasamy-Lucey et al., 2006, 2007). Because UF-concentrated buttermilk has 
a lower lactose content, it tends to give rise to cheeses with a higher $\mathrm{pH}$ and less acidity (Govindasamy-Lucey et al., 2007). Studies indicate that the level of substitution of concentrated buttermilk cannot exceed 5 to $10 \%$. To obtain an acceptable curd, many changes are required in the cheese-making process. The main change consists of raising the temperature during the cooking step to increase whey syneresis (Govindasamy-Lucey et al., 2007). Many studies have shown that cheeses made with buttermilk or concentrated buttermilk tend to retain 3 to $5 \%$ more moisture than control cheeses (Turcot et al., 2001; Govindasamy-Lucey et al., 2006, 2007). It has been suggested that the MFGM particles or phospholipids in buttermilk are responsible for the high moisture of cheeses made with buttermilk; however, no mechanism has been proposed to explain this. Another hypothesis that has frequently been put forward is that the heat treatment the cream undergoes before churning promotes significant denaturation of whey proteins, leading to poor rennet coagulation properties in the buttermilk (Govindasamy-Lucey et al., 2006). Because of the high variability involved and the impossibility of knowing exactly how much heat was applied to the commercial cream used to make the butter and to the buttermilk itself, most studies have not been able to fully explain the effects produced by adding commercial buttermilk to cheese milk.

The objective of this study was to determine the cause of the adverse effects that adding buttermilk to cheese milk has on the properties of rennet gels. For each buttermilk type produced, a skim milk control with the same heat treatment history was used. The present research focused on the coagulation and mechanical properties of rennet milk gels made with buttermilk as well as on the manufacture of model cheeses in miniature cheese vats.

\section{MATERIALS AND METHODS}

Ingredient Manufacture. Three types of skim milk (raw, pasteurized, and separated from pasteurized whole milk) and 3 types of buttermilk (from raw, pasteurized, or cream separated from pasteurized whole milk) were prepared from the same batch of raw milk. Figure 1 shows the schematic of the preparation of the 6 fractions. In all, $300 \mathrm{~L}$ of raw milk was purchased from Agropur Cooperative (Granby, Quebec, Canada). Milk composition was determined by infrared analysis (MilkoScan FT-120, Foss North America, Brampton, Ontario, Canada). Of this amount, $250 \mathrm{~L}$ was heated to $40^{\circ} \mathrm{C}$ and skimmed by using a pilot-scale milk separator (model 62181m-60, Alfa Laval, Uppsala, Sweden). A sample of skim milk (5 L) was then batch pasteurized $\left(68^{\circ} \mathrm{C}, 30 \mathrm{~min}\right)$, cooled to $4^{\circ} \mathrm{C}$, and frozen $\left(-28^{\circ} \mathrm{C}\right)$ until further analysis. Some raw skim milk (5 L) was also frozen. The rest of the raw skim milk $(\sim 220 \mathrm{~L})$ was UF through two 10-kDa membranes (Romicon, Koch Membrane Systems, Wilmington, MA) to a volumetric concentration factor of $3 \times$ at $45^{\circ} \mathrm{C}$. The retentate $(5 \mathrm{~L})$ and the permeate $(5 \mathrm{~L})$ were kept frozen until use for cheese milk standardization. The raw cream (3 L) was adjusted to $35 \%$ milk fat by mixing it with the appropriate amount of raw skim milk. Half of the cream volume was batch pasteurized at $68^{\circ} \mathrm{C}$ for $30 \mathrm{~min}$ and rapidly cooled to $4^{\circ} \mathrm{C}$. Both creams (raw and pasteurized) were stored at $4^{\circ} \mathrm{C}$ overnight. To obtain skim milk and buttermilk with the same heat treatment history, part of the raw whole milk ( $50 \mathrm{~L}$ ) was batch pasteurized $\left(68^{\circ} \mathrm{C}, 30 \mathrm{~min}\right)$ before being separated into skim milk and cream (35\% milk fat) at $40^{\circ} \mathrm{C}$. The cream was rapidly cooled to $4^{\circ} \mathrm{C}$ and stored overnight at $4^{\circ} \mathrm{C}$. A 5$\mathrm{L}$ portion of skim milk was kept frozen until further analysis. On the following day, the 3 creams were churned to butter and buttermilk in a mixer (model 200-T, Hobart, Troy, OH) at $4^{\circ} \mathrm{C}$. Buttermilks were recovered by filtration through cheesecloth. They were then centrifuged $\left(6,000 \times g, 10 \mathrm{~min}, 20^{\circ} \mathrm{C}\right.$; model Avanti J-20 XPI, Beckman Coulter, Mississauga, Ontario, Canada) to remove excess fat and filtered through glass wool, after which they were frozen until further analysis. The whole process of ingredient manufacture was repeated on 3 different occasions.

Compositional Analysis. Samples of skim milks, buttermilks, retentates, permeates, and wheys from model cheese manufacture were analyzed for TS by dehydration in a vacuum oven at $102^{\circ} \mathrm{C}$ for $5 \mathrm{~h}$ (method 990.20; AOAC, 2000). True protein and $\mathrm{pH} 4.6$-soluble and $\mathrm{pH}$ 4.6-insoluble protein contents were determined by the Kjeldahl method (method 991.22; AOAC, 2000). Lipids were determined by a modified Mojonnier procedure. Samples were extracted in Mojonnier flasks and the solvent phase was decanted into $250-\mathrm{mL}$ rotary evaporator flasks. After the extraction, the solvent was evaporated by using a vacuum rotary evaporator (Rotavapor R-124, Büchi Labortechnik, Postfach, Switzerland) at $45^{\circ} \mathrm{C}$. Lipid-containing flasks were dried in a forced-air oven at $75^{\circ} \mathrm{C}$ for $30 \mathrm{~min}$. The flasks were then weighed, and an appropriate amount of 2:1 methanolchloroform mixture was added to obtain a concentration of $10 \mathrm{mg} / \mathrm{mL}$. Extracted lipids were then stored at $-20^{\circ} \mathrm{C}$ until further analysis. Phospholipids in the Mojonnier extracts were quantified by HPLC coupled with evaporative light-scattering detection as described previously (Morin et al., 2006). Protein profiles of the buttermilks, $\mathrm{pH} 4.6$ precipitates, and supernatant were obtained by SDS-PAGE on $12 \%$ acrylamide gels, and profiles of wheys from cheese manufacture were obtained on $15 \%$ 


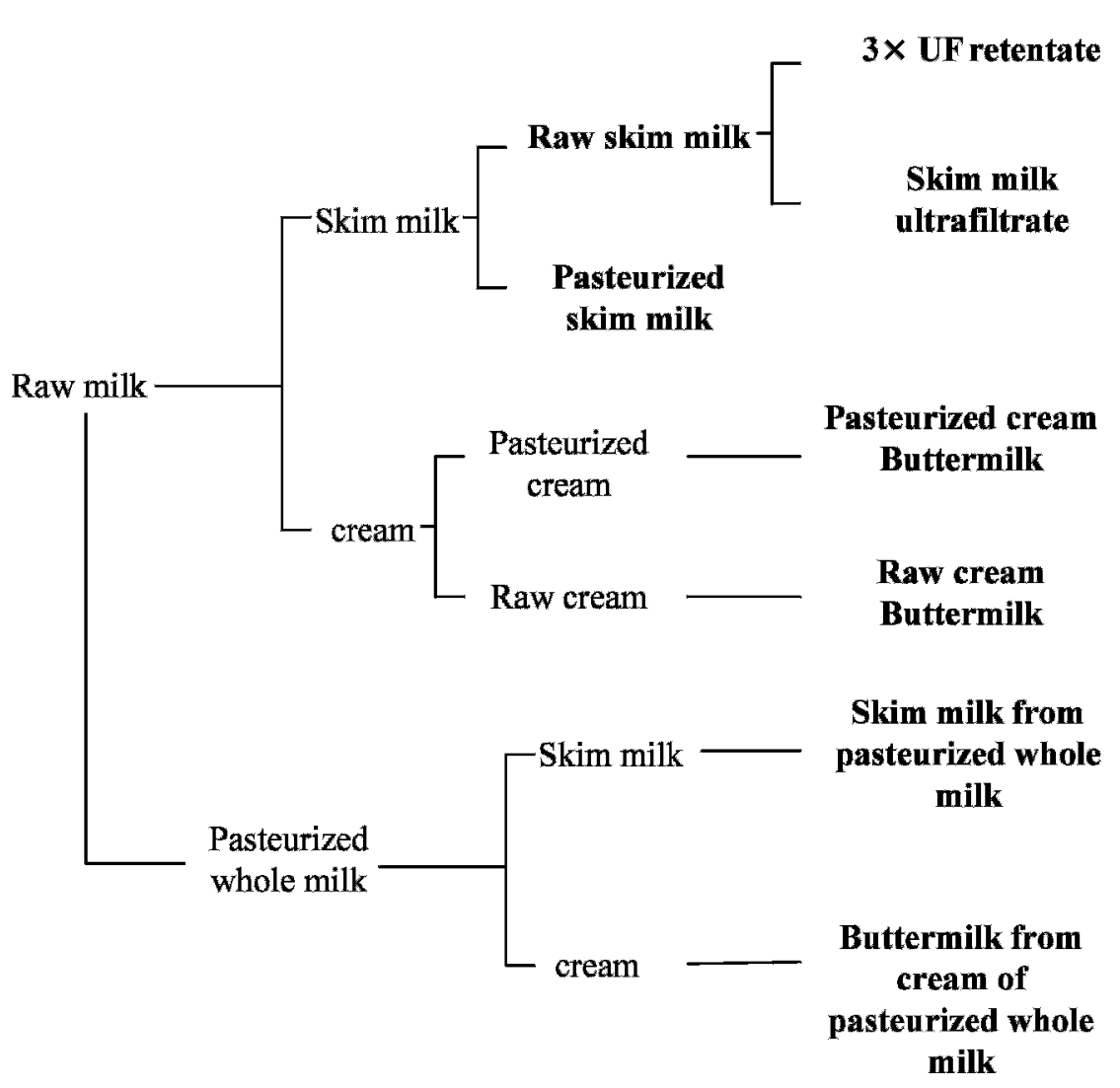

Figure 1. Schematic representation of ingredient manufacture.

acrylamide gels as described by Morin et al. (2007a). All reagents were of HPLC or electrophoresis grade.

Cheese Milk Standardization. Cheese milks were made with the 3 skim milks and 3 buttermilks (Figure 1). Milks were standardized with $50 \%$ of the true protein originating from the ingredient and with the rest from the raw skim milk UF retentate and pasteurized cream (Fromagerie Corneville, Agropur Cooperative, St-Hyacinthe, Quebec, Canada). The cream used for standardization was batch pasteurized $\left(68^{\circ} \mathrm{C}, 30 \mathrm{~min}\right)$ and analyzed for total fat, TS, and total proteins by using a MilkoScan FT-120 instrument. Unless otherwise stated, the true protein content in standardized milks was set at $3.5 \%$ and the milk fat content was set at $2 \%$, using an appropriate amount of raw skim milk permeate. Milks were adjusted to $\mathrm{pH} 6.57 \pm 0.02$ with $40 \%$ lactic acid, unless otherwise indicated. In every experiment, rennet (Maxiren Double Strength, DSM Food Specialties USC Inc., Parsippany, NJ) was added to the milk at $0.0055 \%$ after $1: 10$ dilution in Milli-Q water (Millipore, Billerica, MA).

\section{Rennet Gel Characterization}

Rennet Coagulation Kinetics. Rennet coagulation kinetics of the 6 different milks were evaluated by opti- cal density measurement (650 $\mathrm{nm}$ ) using 96-well microplates and a microplate reader (Ultra Microplate Reader LE 808, BioTek Instruments Inc., Winooski, VT) according to the method of Robitaille et al. (2004). Samples used for coagulation kinetics were standardized for true proteins (3.5\%), but no cream was added because fat causes an excessive increase in the optical density of milks and reduced detection sensitivity. Briefly, milks were tempered at $34^{\circ} \mathrm{C}$ for $20 \mathrm{~min}$ and a $45-\mu \mathrm{L}$ portion was mixed with $5 \mu \mathrm{L}$ of diluted rennet. Optical density was read at $34^{\circ} \mathrm{C}$ every $30 \mathrm{~s}$ for a period of $60 \mathrm{~min}$. Coagulation kinetic measurements of milks from the 3 replicates were analyzed 5 times and averaged. Optical density was normalized to account for the different initial turbidity values of the different milks by using equation [1]:

$$
\mathrm{OD}_{\text {Normalized }}=\frac{\mathrm{OD}_{\mathrm{t}}-\mathrm{OD}_{\mathrm{t}=0}}{\mathrm{OD}_{\max }-\mathrm{OD}_{\mathrm{t}=0}}
$$

where $\mathrm{OD}_{\mathrm{t}}$ is the optical density at time $\mathrm{t}, \mathrm{OD}_{\mathrm{t}=0}$ is the initial optical density of the milk, and $\mathrm{OD}_{\max }$ is the optical density after $60 \mathrm{~min}$. Optical density was plotted against time, and the curves were fitted to a sigmoid 
equation with 5 coefficients (equation [2]) by using SigmaPlot 8.0 (SPSS Inc., Chicago, IL):

$$
f(x)=\frac{(a-d)}{\left[1+(x / c)^{b}\right]^{e}+d} .
$$

The first and second derivatives of the equations were calculated to obtain the lag time $\left(\mathrm{T}_{\text {lag }}\right)$ and maximum coagulation rate $\left(R_{\max }\right)$.

Cutting Time and Firmness of Rennet Gels. The cutting time for all cheese milks was evaluated by dynamic rheology with a constant-stress rheometer with a bob and cup configuration (SR-2000, Rheometric Scientific, Piscataway, NJ). The parameters used for the experiments were $0.5 \mathrm{~Pa}$ of stress and a $0.01-\mathrm{Hz}$ frequency at $34^{\circ} \mathrm{C}$. Briefly, $20 \mathrm{~mL}$ of milk was tempered at $34^{\circ} \mathrm{C}$ for $20 \mathrm{~min}$ before addition of rennet. A $13.4 \mathrm{-g}$ quantity of the renneted milk was then transferred to the cup of the rheometer and mineral oil was layered on top of the milk to prevent evaporation. Measurements were started when gel strength $\left(\mathrm{G}^{\prime}\right)$ was greater than $1 \mathrm{~Pa}$. Cutting time was defined as the time needed to reach a $\mathrm{G}^{\prime}$ of $20 \mathrm{~Pa}$ (Guinee et al., 1997). Gel firmness 60 min after renneting was also recorded. Each milk from the 3 repetitions was analyzed in triplicate.

Contraction Capacity. Contraction capacity of the different rennet gels was evaluated by measuring the percentage of syneresis obtained after $2.5 \mathrm{~h}$ at $42^{\circ} \mathrm{C}$. Briefly, $20 \mathrm{~mL}$ of milk was tempered at $34^{\circ} \mathrm{C}$ for $20 \mathrm{~min}$ before rennet addition; $5 \mathrm{~g}$ of renneted milk was then transferred to a glass tube (i.d. $=13 \mathrm{~mm}$ ), which was held at $34^{\circ} \mathrm{C}$ until cutting time $(20 \mathrm{~Pa})$ was reached. The tube was then transferred to a water bath at $42^{\circ} \mathrm{C}$ and held for $2.5 \mathrm{~h}$. The mass of syneresis liquid was measured after curd drainage for 2 min on a mesh. Percentage of syneresis was calculated with equation [3]:

$$
\% \text { syneresis }=\left(\frac{\text { syneresis liquid mass }}{\text { initial milk mass }}\right) \times 100 .
$$

All milks derived from the 3 repetitions were analyzed in triplicate.

Microstructure Observation. Scanning electron microscopy images of gels were obtained by using the curds from the contraction capacity measurement. The curds were rapidly frozen in liquid nitrogen and then freeze-dried. Curd pieces were fractured with the strike of a scalpel, placed on an aluminum stub, and then covered with 15 to $20 \mathrm{~nm}$ of gold. Observations were made with a Hitachi S-3000N scanning electron microscope (Hitachi, Pleasanton, CA) at $5 \mathrm{kV}$ and a working distance of approximately $10 \mathrm{~mm}$.
Model Cheese Manufacture. Laboratory-scale manufacture of model cheese was carried out in 144$\mathrm{mL}$ cheese vats with Plexiglas covers layered with cheesecloth, allowing for whey recovery. Before model cheese making, milk was tempered at $34^{\circ} \mathrm{C}$ for $20 \mathrm{~min}$ and the $\mathrm{pH}$ was adjusted to $6.2 \pm 0.02$ with $40 \%$ lactic acid. A $150-\mathrm{mL}$ quantity of cheese milk was then renneted and $144 \mathrm{~mL}$ was poured into the cheese vat. The cheese vat was placed in an orbital shaking water bath (model C-76, New Brunswick Scientific, Edison, NJ) at $34^{\circ} \mathrm{C}$ until cutting time was reached, as measured by dynamic rheometry. Cutting was done by using a $1-\mathrm{cm}-$ spaced 11-blade stainless steel knife to obtain $1-\mathrm{cm}^{3}$ curd particles. The curds were then agitated at $50 \mathrm{rpm}$ and $34^{\circ} \mathrm{C}$ for $15 \mathrm{~min}$, after which the temperature was gradually raised to $40^{\circ} \mathrm{C}$ in $30 \mathrm{~min}\left(1^{\circ} \mathrm{C}\right.$ per $\left.5 \mathrm{~min}\right)$ with 90-rpm agitation. Curd drainage was done by reversing the vats to recover whey in the vat cover. Drainage was carried out at $38^{\circ} \mathrm{C}$ for $60 \mathrm{~min}$ without agitation. Curds were then transferred into a 50-mL tube and centrifuged at $10,000 \times g$ for $30 \mathrm{~min}$ at $32^{\circ} \mathrm{C}$ (Sorvall RC5B Superspeed, Thermo Fisher Scientific, Waltham, MA). Wheys from drainage and centrifugation were pooled and the mass of the whey and curd were recorded. Actual yield (equation [4]) and moisture- and whey solidscorrected yield (equation [5]) were calculated:

$$
\begin{gathered}
\text { actual yield }(\mathrm{AY}, \%)=\left(\frac{\text { mass of curd }}{\text { mass of milk }}\right) \\
\times 100, \text { and } \\
\text { corrected yield }(\%)= \\
\text { AY } \times\left(\frac{100-\mathrm{CM}-\mathrm{WS}}{100-\mathrm{RCM}-\mathrm{RWS}}\right)
\end{gathered}
$$

where $\mathrm{CM}$ is curd moisture, $\mathrm{RCM}$ is reference curd moisture, WS is whey solids, and RWS is reference whey solids. For corrected yield calculations, raw skim milk model cheese moisture and whey solids were used as the reference. Retention coefficients were also calculated for proteins, lipids, and phospholipids (equation [6]):

$$
\begin{aligned}
& \% \text { retention }= \\
& \left\{100 \times\left[1-\frac{(\% \text { protein, lipid, or phospholipid in whey })}{(\% \text { protein, lipid, or phospholipid in cheese milk) })}\right]\right\} \text {. }
\end{aligned}
$$

Model cheese manufacture was carried out once for each sample from the 3 replicates.

Statistical Analysis. The effect of type of milk (skim, buttermilk) and heat treatment (raw, pasteurized before skimming, or pasteurized after skimming) 
Table 1. Average $(n=3)$ composition of skim milk and buttermilk ingredients

\begin{tabular}{|c|c|c|c|c|c|c|c|}
\hline \multirow[b]{2}{*}{ Item } & \multicolumn{3}{|c|}{ Skim milks } & \multicolumn{3}{|c|}{ Buttermilks } & \multirow[b]{2}{*}{ SEM } \\
\hline & Raw & Pasteurized & $\begin{array}{c}\text { WM } \\
\text { pasteurized }^{1}\end{array}$ & $\begin{array}{c}\text { Raw } \\
\text { cream }\end{array}$ & $\begin{array}{l}\text { Pasteurized } \\
\text { cream }\end{array}$ & $\begin{array}{c}\text { WM } \\
\text { pasteurized }\end{array}$ & \\
\hline True protein ${ }^{2}(\%)$ & $3.27^{\mathrm{ab}}$ & $3.30^{\mathrm{a}}$ & $3.24^{\mathrm{ab}}$ & $3.12^{\mathrm{ab}}$ & $3.12^{\mathrm{ab}}$ & $3.11^{b}$ & 0.06 \\
\hline pH 4.6-insoluble protein ${ }^{3}(\%)$ & $2.63^{\mathrm{abc}}$ & $2.76^{\mathrm{a}}$ & $2.70^{\mathrm{ab}}$ & $2.35^{\mathrm{d}}$ & $2.58^{\mathrm{bc}}$ & $2.53^{\mathrm{c}}$ & 0.06 \\
\hline pH 4.6 -soluble protein $(\%)$ & $0.64^{\mathrm{b}}$ & $0.54^{\mathrm{c}}$ & $0.53^{\mathrm{c}}$ & $0.77^{\mathrm{a}}$ & $0.54^{\mathrm{c}}$ & $0.58^{\mathrm{bc}}$ & 0.03 \\
\hline pH 4.6 -insoluble protein in true protein $(\%)$ & $80.4^{\mathrm{c}}$ & $83.8^{\mathrm{a}}$ & $83.5^{\mathrm{ab}}$ & $75.4^{\mathrm{d}}$ & $82.6^{\text {abc }}$ & $81.2^{\mathrm{bc}}$ & 0.8 \\
\hline Phospholipids (\%) & $0.015^{\mathrm{c}}$ & $0.014^{\mathrm{c}}$ & $0.015^{\mathrm{c}}$ & $0.102^{\mathrm{b}}$ & $0.119^{\mathrm{a}}$ & $0.096^{\mathrm{b}}$ & 0.003 \\
\hline Phosphatidylethanolamine & $29.2^{\mathrm{b}}$ & $29.8^{\mathrm{b}}$ & $29.1^{\mathrm{b}}$ & $39.0^{\mathrm{a}}$ & $41.2^{\mathrm{a}}$ & $42.7^{\mathrm{a}}$ & 2.6 \\
\hline Phosphatidylcholine & $29.6^{\mathrm{a}}$ & $27.0^{\mathrm{a}}$ & $28.9^{\mathrm{a}}$ & $26.8^{\mathrm{a}}$ & $25.9^{\mathrm{a}}$ & $25.4^{\mathrm{a}}$ & 2.9 \\
\hline Phosphatidylinositol & $8.6^{\mathrm{a}}$ & $9.0^{\mathrm{a}}$ & $8.3^{\mathrm{a}}$ & $8.6^{\mathrm{a}}$ & $8.2^{\mathrm{a}}$ & $8.1^{\mathrm{a}}$ & 2.2 \\
\hline Phosphatidylserine & $9.3^{\mathrm{a}}$ & $9.6^{\mathrm{a}}$ & $9.8^{\mathrm{a}}$ & $10.0^{\mathrm{a}}$ & $9.9^{\mathrm{a}}$ & $9.4^{\mathrm{a}}$ & 1.5 \\
\hline Sphingomyelin & $23.3^{\mathrm{a}}$ & $24.7^{\mathrm{a}}$ & $24.0^{\mathrm{a}}$ & $15.7^{\mathrm{b}}$ & $14.9^{\mathrm{b}}$ & $14.5^{\mathrm{b}}$ & 1.2 \\
\hline
\end{tabular}

${ }^{\mathrm{a}-\mathrm{c}}$ Means with different superscripts in the same row differ $(P<0.05)$.

${ }^{1}$ Whole raw milk pasteurized before skimming.

${ }^{2}$ True protein $=($ total $\mathrm{N}-\mathrm{NPN}) \times 6.38$.

${ }^{3} \mathrm{pH} 4.6$-insoluble protein $=($ total $\mathrm{N}-\mathrm{pH} 4.6$-soluble $\mathrm{N}) \times 6.38$.

${ }^{4}$ Neutral lipids $=$ total lipids - phospholipids.

on the properties of rennet gels and model cheeses was tested according to a factorial design. Statistical analysis was carried out by using SAS software (SAS Institute Inc., Cary, NC), specifically the PROC GLM procedure with least squares means multiple comparisons. Results were considered significantly different when $P$ $<0.05$.

\section{RESULTS AND DISCUSSION}

\section{Ingredient Compositions}

The average composition $(\mathrm{n}=3$ ) of the skim milks and the buttermilks is shown in Table 1. Pasteurization of milk before or after skimming did not produce a significant change in TS or true protein content. On average, true protein concentration was slightly lower in buttermilks $(3.12 \%)$ than in skim milks $(3.27 \%)$, suggesting protein retention during the cream-churning process $(P=0.0087)$. The fraction of insoluble protein at $\mathrm{pH} 4.6$ in raw skim milk was $80.4 \%$, which is in agreement with the average $\mathrm{CN}$ proportion in milk protein (Walstra et al., 2006). However, the corresponding proportion was much lower in buttermilk from raw cream (75.4\%), which could be explained by a decrease in the $\mathrm{pH} 4.6$-insoluble fraction and an increase in the $\mathrm{pH} 4.6$-soluble fraction. This result suggests that a portion of $\mathrm{CN}(\sim 10 \%)$ was retained in the butter matrix during cream churning and that MFGM proteins were released into the buttermilk. Pasteurization of milk before or after skimming induced whey protein denaturation and increased the fraction of insoluble protein at $\mathrm{pH} 4.6$ from $80.4 \%$ to approximately $83.6 \%$. Pasteuriza- tion of cream or whole milk before butter making had an even greater effect on the fraction of insoluble protein at $\mathrm{pH} 4.6$ in buttermilks, which increased from $75.4 \%$ to more than $81 \%$. This result suggests that the solubility of MFGM protein at $\mathrm{pH} 4.6$ was severely affected by pasteurization. Sodium dodecyl sulfate-PAGE analysis of $\mathrm{pH} 4.6$-soluble and $\mathrm{pH}$ 4.6-insoluble protein was carried out (Figure 2) and confirmed that heating of cream or whole milk reduced the concentration of MFGM protein in the $\mathrm{pH} 4.6$-soluble fraction in the resulting buttermilks (Figure 2, lane 4 vs. lanes 7 and 10). Milk fat globule membrane proteins mostly remained in the supernatant when no heat was applied to the cream or to the whole milk before skimming (Figure 2, lane 4). However, our results did not allow us to determine whether milk or cream pasteurization induced direct interactions between CN micelles and MFGM protein or between whey proteins and MFGM proteins. Heat treatment has been shown to induce whey protein adsorption at the surface of milk fat globules (Dalgleish and Banks, 1991; Ye et al., 2002). The pH 4.6 solubility of MFGM fragments covered with denatured whey protein might therefore be reduced. The exact nature of the changes that occur in the MFGM upon heating in either a milk or cream environment is not fully understood (Evers, 2004) and would need further investigation.

The lipid contents of skim milks and buttermilks are also shown in Table 1. Buttermilks had a significantly higher lipid content than skim milk even after centrifugation $(P<0.0001)$. The phospholipid content was also 8 to 10 times higher for buttermilk, which is consistent 


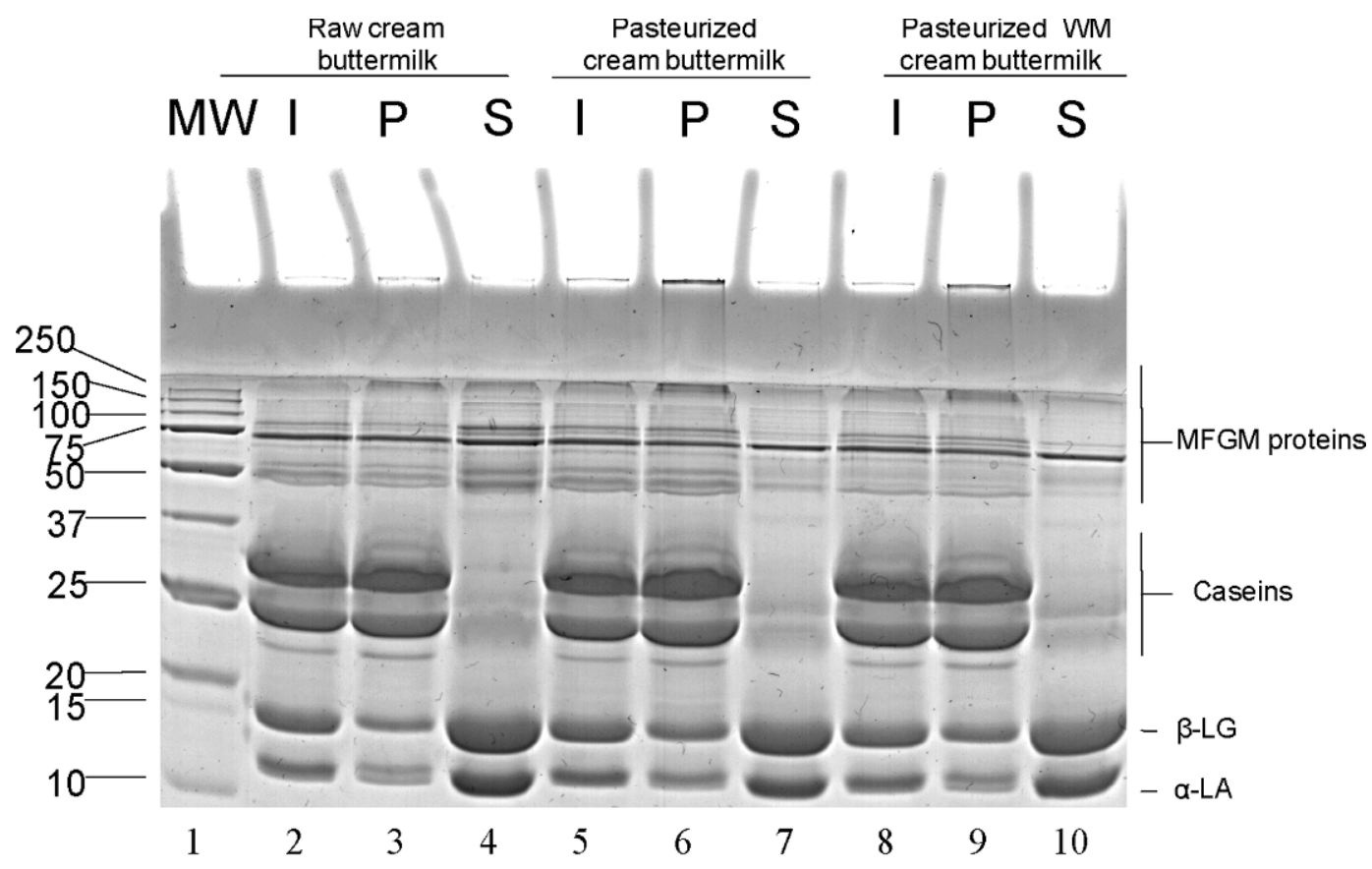

Figure 2. Sodium dodecyl sulfate-PAGE (12.0\% acrylamide) profile of (I) initial buttermilk, (P) $\mathrm{pH} 4.6 \mathrm{precipitate,} \mathrm{and} \mathrm{(S)} \mathrm{pH} 4.6$ supernatant. Initial buttermilks and supernatant were diluted 1:10 and 1:2, respectively, with sample buffer. Precipitates were dissolved $(50 \mathrm{mg} / \mathrm{mL})$ in sample buffer. $\mathrm{MW}=$ molecular weight $(\mathrm{kDa}) ; \mathrm{WM}=$ whole milk; MFGM = milk fat globule membrane.

with reported values (Christie et al., 1987; Rombaut et al., 2006). The phospholipid content of pasteurized cream buttermilk was significantly higher than that of raw cream or pasteurized whole milk buttermilk. Trapping of MFGM particles (rich in phospholipids) in the butter after churning appeared to be lowered in the case of pasteurized cream, resulting in higher levels of phospholipids in the buttermilk. Interaction of MFGM particles with skim milk protein could modify the hydrophobicity of MFGM particles and therefore affect their distribution between the aqueous phase (buttermilk) and the lipid phase (butter). The concentrations of phospholipid species were similar in the 3 skim milks and in the 3 buttermilks. However, the skim milks contained significantly less phosphatidylethanolamine and significantly more sphingomyelin. It has been suggested that the positioning of phospholipids in the MFGM could be responsible for the different profiles observed in different dairy products (Rombaut et al., 2006; Morin et al., 2007b). Separation of milk creates high shear at the surface of fat globules, and loosely bound phospholipids on the outer side of the MFGM could be released into the skim milk, leading to a cream fraction rich in firmly bound phospholipids (mainly phosphatidylethanolamine) and less concentrated in sphingomyelin.

\section{Rennet Coagulation Kinetics}

Optical measurement of coagulation of the different protein-standardized cheese milks was carried out in a microplate format. Parameters obtained by derivation of the model equation (equation [2]) are shown in Table 2 . The lag time before the first sign of aggregation ranged from 9.84 to 11.69 min. Milk standardized with raw cream buttermilk, however, started to coagulate significantly faster than milk standardized with buttermilk from pasteurized cream or cream separated from pasteurized whole milk. This trend was not observed for the effect of pasteurization on skim milk ingredients. The lag time was determined mainly by the ability of rennet to hydrolyze the $\mathrm{Phe}_{105}-\mathrm{Met}_{106}$ bond of $\kappa$-CN. The deposition of denatured whey proteins and MFGM proteins on the surface of CN micelles could create steric hindrance and slow the hydrolysis rate. However, it has been demonstrated in heated skim milks that the denaturation caused by heating does not affect the rennetability of milks, but rather the aggregation of $\mathrm{CN}$ particles in the secondary stage of coagulation (Vasbinder et al., 2003). On average, the maximum coagulation rate was significantly $(P=0.025)$ lower in cheese milks standardized with buttermilk $\left(0.090 \mathrm{~min}^{-1}\right)$ than with skim milk $\left(0.103 \mathrm{~min}^{-1}\right)$. Poor coagulation proper- 
Table 2. Average $(n=3)$ rennet coagulation kinetics optical parameters of milk standardized with skim milk and buttermilk ingredients

\begin{tabular}{|c|c|c|c|c|c|c|c|}
\hline \multirow[b]{2}{*}{ Item } & \multicolumn{3}{|c|}{ Skim milks } & \multicolumn{3}{|c|}{ Buttermilks } & \multirow[b]{2}{*}{ SEM } \\
\hline & Raw & Pasteurized & $\begin{array}{c}\text { WM } \\
\text { pasteurized }^{1}\end{array}$ & $\begin{array}{l}\text { Raw } \\
\text { cream }\end{array}$ & $\begin{array}{l}\text { Pasteurized } \\
\text { cream }\end{array}$ & $\begin{array}{c}\text { WM } \\
\text { pasteurized }\end{array}$ & \\
\hline $\mathrm{T}_{\text {lag }}(\min )$ & $11.04^{\mathrm{ab}}$ & $11.36^{\mathrm{a}}$ & $11.02^{\mathrm{ab}}$ & $9.84^{\mathrm{b}}$ & $11.69^{\mathrm{a}}$ & $11.14^{\mathrm{a}}$ & 0.40 \\
\hline $\mathrm{R}_{\max }\left(\min ^{-1}\right)$ & $0.098^{\mathrm{ab}}$ & $0.100^{\mathrm{ab}}$ & $0.110^{\mathrm{a}}$ & $0.088^{\mathrm{bc}}$ & $0.078^{\mathrm{c}}$ & $0.103^{\mathrm{ab}}$ & 0.006 \\
\hline
\end{tabular}

${ }^{\mathrm{a}-\mathrm{c}}$ Means with different superscripts in the same row differ $(P<0.05)$.

${ }^{1}$ Whole raw milk pasteurized before skimming.

ties of buttermilk have been observed previously (Joshi et al., 1994) and have been attributed to the higher concentration of phospholipids (Table 1). The negative effect of buttermilk on the coagulation rate of cheese milk depended on the thermal history of the cream before churning $(P=0.046)$. The lowest coagulation rate was observed when buttermilk was obtained from pasteurized cream. However, when pasteurization was applied to whole milk (before separation), the maximum coagulation rate was increased by more than $30 \%$. On the basis of coagulation kinetics, pasteurization of the cream appeared to be the main explanation for the poor coagulation properties of buttermilk. However, because pasteurization of the cream caused an increase in the phospholipid content of the buttermilk (Table 1), it was difficult to clearly distinguish the effects of both cream pasteurization and phospholipid content from our results.

\section{Rennet Gel Rheology and Contraction Capacity}

Constant stress rheometry was used to evaluate the evolution of firmness $\left(G^{\prime}\right)$ for a period of 60 min after rennet addition. In addition, the set-to-cut time was determined as the time needed to reach a $\mathrm{G}^{\prime}$ of $20 \mathrm{~Pa}$. Table 3 shows the average cutting time and firmness of rennet gels after $60 \mathrm{~min}$. Significant differences could be observed between different milks standardized with either buttermilk or skim milk ingredients for both cutting time $(P=0.032)$ and final firmness $(P=0.001)$.
Rennet gels containing buttermilk ingredients were characterized by a very slow increase in storage modulus. Coagulation of milk standardized with pasteurized cream buttermilk was slowest, as shown by the very long cutting time, which corroborates the data from optical coagulation kinetic measurements. The gel formed with milk containing pasteurized cream buttermilk was very weak; its firmness at 60 min was approximately 2.5 times less than that of raw skim milk. Milk standardized with buttermilk made from pasteurized cream or whole milk showed a significantly lower firmness than raw skim milk, but was similar to milk containing pasteurized skim milk. These results suggest that even if pasteurization of the cream was the main reason for the altered coagulation properties of buttermilks, the presence of MFGM particles modified the coagulation process to an extent comparable to the pasteurization of milk. It should also be noted that because the milks were standardized on a true protein basis, cheese milks containing buttermilk had approximately $5 \%$ less $\mathrm{CN}$ than cheese milks with skim milk. Although minimal, this difference in $\mathrm{CN}$ content could also be partly responsible for the observed differences. Interestingly, when pasteurization was applied before separation, the effects of buttermilk and skim milk on the rheological properties of rennet gel were not significantly different from those of raw buttermilk and skim milk. However, when pasteurization was applied after separation, the resulting buttermilk and skim milk had significant and negative effects on rennet gel firmness

Table 3. Average $(n=3)$ rheological parameters of rennet gels obtained from milk standardized with skim milk and buttermilk ingredients

\begin{tabular}{|c|c|c|c|c|c|c|c|}
\hline \multirow[b]{2}{*}{ Item } & \multicolumn{3}{|c|}{ Skim milks } & \multicolumn{3}{|c|}{ Buttermilks } & \multirow[b]{2}{*}{ SEM } \\
\hline & Raw & Pasteurized & $\begin{array}{c}\text { WM } \\
\text { pasteurized }^{1}\end{array}$ & $\begin{array}{l}\text { Raw } \\
\text { cream }\end{array}$ & $\begin{array}{l}\text { Pasteurized } \\
\text { cream }\end{array}$ & $\begin{array}{c}\text { WM } \\
\text { pasteurized }\end{array}$ & \\
\hline Set-to-cut time ${ }^{2}(\min )$ & $28.3^{\mathrm{b}}$ & $37.5^{\mathrm{ab}}$ & $27.9^{\mathrm{b}}$ & $33.0^{\mathrm{b}}$ & $44.6^{\mathrm{a}}$ & $36.3^{\mathrm{ab}}$ & 3.4 \\
\hline Firmness $(\mathrm{Pa})$ at $\mathrm{T}=60 \mathrm{~min}$ & $91.0^{\mathrm{a}}$ & $56.8^{\mathrm{bc}}$ & $77.6^{\mathrm{ab}}$ & $59.2^{\mathrm{bc}}$ & $36.1^{\mathrm{c}}$ & $54.3^{\mathrm{c}}$ & 6.9 \\
\hline Contraction capacity $(\%)$ & $39.7^{\mathrm{a}}$ & $38.7^{\mathrm{a}}$ & $40.8^{\mathrm{a}}$ & $36.5^{\mathrm{a}}$ & $31.0^{\mathrm{b}}$ & $37.8^{\mathrm{a}}$ & 1.5 \\
\hline
\end{tabular}

${ }^{\mathrm{a}-\mathrm{c}}$ Means with different superscript in the same row differ $(P<0.05)$.

${ }^{1}$ Whole raw milk pasteurized before skimming.

${ }^{2}$ Time required to reach a firmness $\left(\mathrm{G}^{\prime}\right)$ of $20 \mathrm{~Pa}$ after addition of rennet. 
when compared with raw buttermilk and raw skim milk.

Contraction capacity of the rennet gels was measured, and syneresis was significantly higher $(P=$ $0.003)$ in gels made from skim milks $(39.7 \%)$ compared with gels made from buttermilks (35.1\%). The thermal history of both skim milk and buttermilk also influenced the contraction of rennet gels $(P=0.034)$. Contraction capacity of rennet gels was significantly higher when pasteurization was applied before rather than after separation in the preparation of buttermilks. On average, the syneresis of rennet gels made with ingredients derived from pasteurized whole milk was $39.3 \%$, whereas it was only $34.8 \%$ when the ingredients were derived from cream and skim milk pasteurized after separation. Cheese milk with pasteurized cream buttermilk showed the lowest contraction capacity. This indicates that the weak gel formed with this substrate showed poor fusion between particles and therefore could not expel whey efficiently.

\section{Rennet Gel Microstructure}

The microstructure of the rennet gels obtained after the contraction capacity test was studied, and the micrographs are shown in Figure 3. Rennet gels containing raw skim milk (Figure 3a) and raw buttermilk (Figure 3d) showed a very similar microstructure, with large strands and few pores characterized by fairly good uniformity. Pores found in both substrates ranged from 5 to $20 \mu \mathrm{m}$. Rennet gels made with skim milk ingredients became more porous when pasteurized skim milk was used. This was due to whey protein denaturation, which affected the fusion between $\mathrm{CN}$ micelles and therefore created a weaker gel, as observed in rheometry. Rennet gel containing pasteurized cream buttermilk (Figure 3e) showed a completely different microstructure, with an extremely porous structure and very small strands linking particles. This observation corroborates the results obtained by rheometry, in which very weak gels were observed. As observed from the mechanical and optical properties of the gels, the microstructure of rennet gels containing buttermilk made from heated whole milk (Figure 3f) was closer to that containing raw cream buttermilk (Figure 3d) than that with pasteurized buttermilk (Figure 3e). However, the fusion between $\mathrm{CN}$ micelle particles appeared to be incomplete, unlike the gel containing raw cream buttermilk (Figure 3d), and the same observation applied to the rennet gel containing skim milk from pasteurized whole milk (Figure 3c). Considering the very porous structure of pasteurized cream buttermilk rennet gel, cheese standardized with this material is likely to be weak and crumbly, and it may retain higher levels of water because of the inability of the protein particles to contract and expel whey from the curd, as observed in contraction capacity tests.

\section{Model Cheese Manufacture}

To reproduce cheese-making conditions and validate observations related to rennet gel properties, model cheese manufacture was carried out in miniature cheese vats. The knife used for gel cutting generated $1-\mathrm{cm}^{3}$ curds that were cooked, drained, and finally centrifuged to mimic the effect of pressing. Results related to the composition of cheese, the various yields, and retention rates are shown in Table 4. Model cheeses made from milk standardized with buttermilks had a higher moisture content $(\sim 6 \%)$ than those made from milk standardized with raw skim milk $(P=0.0007)$. This result has been observed in many other studies (Raval and Mistry, 1999; Turcot et al., 2001; Govindasamy-Lucey et al., 2006, 2007) and was attributed to the presence of MFGM particles or phospholipids in buttermilk. As a general trend, the phospholipid concentration in cheeses made with buttermilks was approximately 6 times higher than the concentration in cheeses made with skim milk ingredients $(P<0.0001)$. The protein and lipid contents of cheeses made with buttermilks were significantly lower than those for the corresponding skim milks $(P<0.0001)$. This was partly due to higher moisture retention in the curds.

The protein retention coefficient in model cheeses depended on both the ingredient used in cheese milk (skim milk or buttermilk) and the heat treatment applied during preparation of the ingredient $(P=0$ 0.0157). Model cheeses made with raw buttermilk showed significantly lower protein retention than those made with raw skim milk. As previously indicated (Table 1), raw buttermilk was characterized by a lower proportion of $\mathrm{CN}$ and a higher proportion of $\mathrm{pH} 4.6$ soluble protein (mainly MFGM protein). This last protein fraction appeared to be lost in cheese whey. The pasteurization treatment during the preparation of buttermilk increased protein retention in cheese from 74 to $78 \%$. Pasteurization before or after cream separation had similar effects on protein retention. In model cheeses made with skim milk ingredients, the pasteurization treatment had a much smaller effect on protein retention. The retention of MFGM protein appeared to be strongly dependent on the thermal history of buttermilk. Heat treatment could promote the formation of larger MFGM fragments that are physically entrapped in the paracasein network, or it could induce direct interactions with $\mathrm{CN}$ micelles.

The lipid retention coefficient is a good indicator of the strength and cohesion of the paracasein matrix. 
a

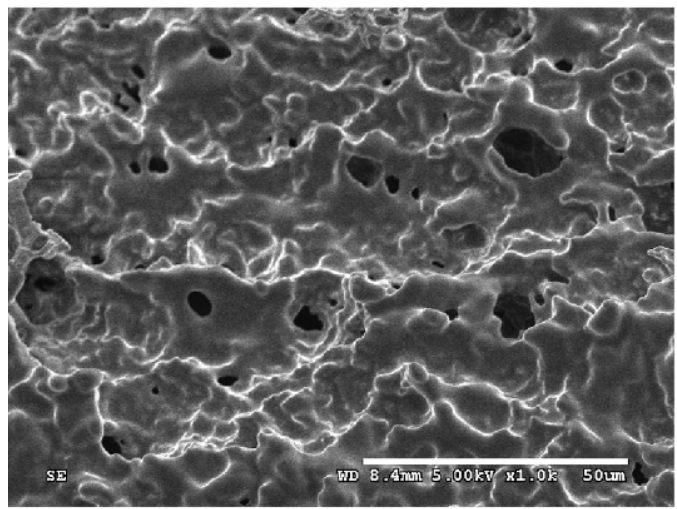

b

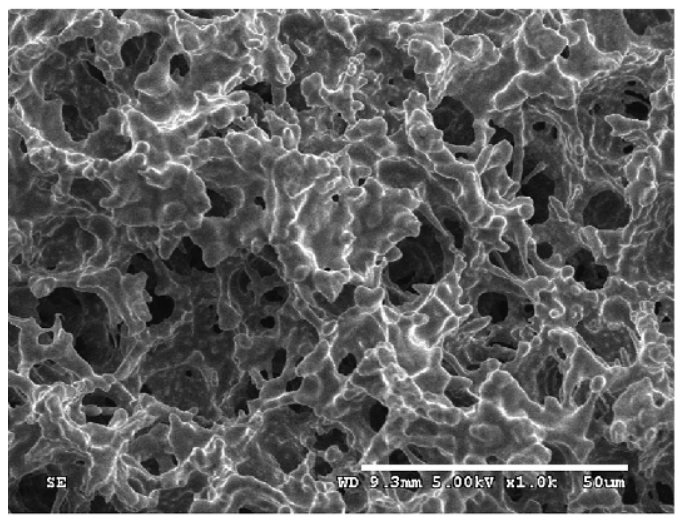

\section{c}

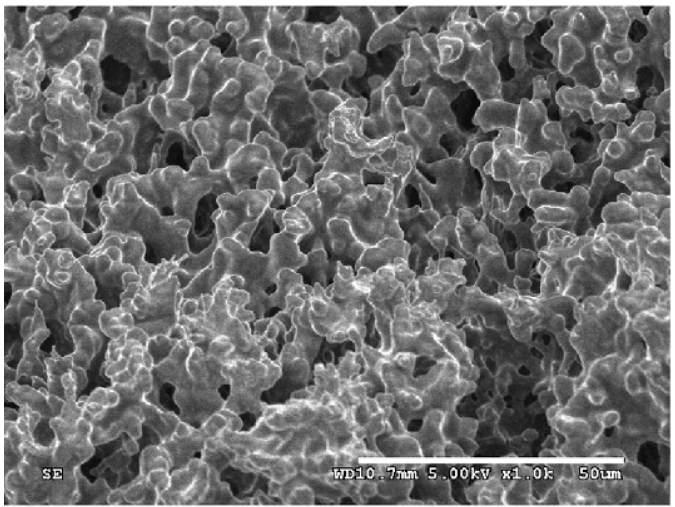

d

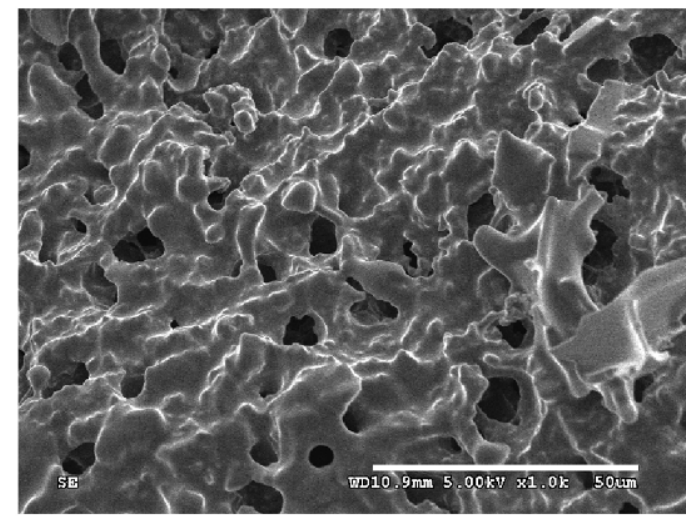

e

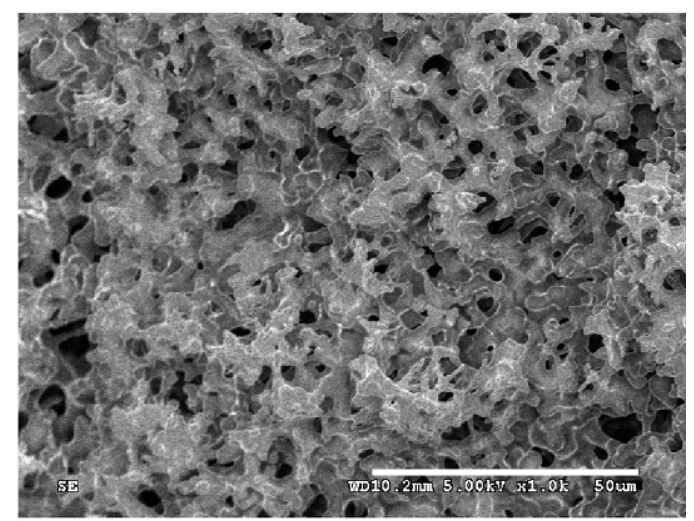

f

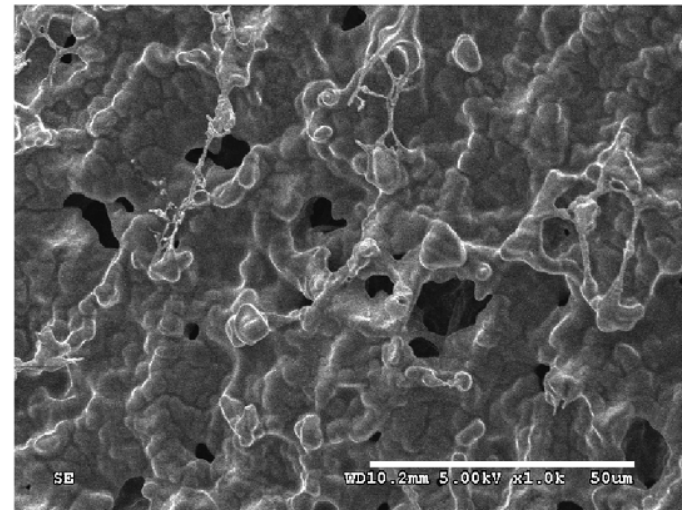

Figure 3. Scanning electron micrographs (1,000×) of rennet gel made from milk standardized with (a) raw skim milk, (b) pasteurized skim milk, (c) skim milk from whole milk pasteurized before skimming, (d) raw cream buttermilk, (e) pasteurized cream buttermilk, and (f) buttermilk from cream separated from pasteurized whole milk. Bars are $50 \mu \mathrm{m}$.

The lipid retention coefficient was significantly higher in model cheeses made with skim milk ingredients than in those made with buttermilk ingredients $(P<0$ 0.0001). The ingredient thermal history had no effect on cheeses made with skim milk but significantly influenced lipid retention in cheeses made with buttermilk
$(P=0.0179)$. The lipid retention coefficient decreased from $84.3 \%$ in cheese made with raw buttermilk to $76.0 \%$ when buttermilk was produced from pasteurized cream. Buttermilk from pasteurized cream weakened the paracasein network and increased lipid losses in cheese whey. When pasteurization was applied to whole 
Table 4. Average $(\mathrm{n}=3)$ composition of cheeses made from milk standardized with skim milk and buttermilk ingredients

\begin{tabular}{|c|c|c|c|c|c|c|c|}
\hline \multirow[b]{2}{*}{ Item } & \multicolumn{3}{|c|}{ Skim milks } & \multicolumn{3}{|c|}{ Buttermilks } & \multirow[b]{2}{*}{ SEM } \\
\hline & Raw & Pasteurized & $\begin{array}{c}\text { WM } \\
\text { pasteurized }^{1}\end{array}$ & $\begin{array}{c}\text { Raw } \\
\text { cream }\end{array}$ & $\begin{array}{l}\text { Pasteurized } \\
\text { cream }\end{array}$ & $\begin{array}{c}\text { WM } \\
\text { pasteurized }\end{array}$ & \\
\hline Moisture (\%) & $48.9^{\mathrm{bc}}$ & $46.8^{\mathrm{c}}$ & $46.5^{\mathrm{c}}$ & $53.1^{\mathrm{ab}}$ & $55.8^{\mathrm{a}}$ & $52.7^{\mathrm{ab}}$ & 1.8 \\
\hline True protein (\%) & $29.78^{\mathrm{a}}$ & $29.26^{\mathrm{a}}$ & $29.89^{\mathrm{a}}$ & $27.42^{\mathrm{b}}$ & $26.99^{\mathrm{b}}$ & $26.90^{\mathrm{b}}$ & 0.45 \\
\hline Total lipids (\%) & $19.76^{\mathrm{a}}$ & $19.30^{\mathrm{a}}$ & $19.30^{\mathrm{a}}$ & $17.52^{\mathrm{b}}$ & $15.06^{\mathrm{c}}$ & $16.70^{\mathrm{b}}$ & 0.48 \\
\hline Phospholipids (\%) & $0.045^{\mathrm{c}}$ & $0.037^{\mathrm{c}}$ & $0.041^{\mathrm{c}}$ & $0.191^{b}$ & $0.350^{\mathrm{a}}$ & $0.217^{\mathrm{b}}$ & 0.017 \\
\hline \multicolumn{8}{|l|}{ Yield (\%) } \\
\hline Actual $^{2}$ & $9.54^{\mathrm{b}}$ & $9.68^{b}$ & $9.77^{\mathrm{b}}$ & $9.83^{\mathrm{b}}$ & $10.55^{\mathrm{a}}$ & $10.56^{\mathrm{a}}$ & 0.19 \\
\hline Corrected $^{3}$ & $9.54^{\mathrm{ab}}$ & $10.23^{\mathrm{a}}$ & $10.43^{\mathrm{a}}$ & $8.85^{\mathrm{b}}$ & $8.80^{b}$ & $9.65^{\mathrm{ab}}$ & 0.31 \\
\hline \multicolumn{8}{|l|}{ Retention (\%) } \\
\hline Proteins & $78.6^{\mathrm{b}}$ & $78.7^{\mathrm{b}}$ & $81.0^{\mathrm{a}}$ & $73.9^{\mathrm{c}}$ & $78.2^{\mathrm{b}}$ & $78.1^{\mathrm{b}}$ & 0.6 \\
\hline Lipids & $93.4^{\mathrm{a}}$ & $92.7^{\mathrm{ab}}$ & $93.4^{\mathrm{a}}$ & $84.3^{\mathrm{b}}$ & $76.0^{\mathrm{c}}$ & $90.1^{\mathrm{ab}}$ & 2.0 \\
\hline Phospholipids & $14.3^{\mathrm{b}}$ & $12.1^{\mathrm{b}}$ & $11.8^{\mathrm{b}}$ & $18.5^{\mathrm{b}}$ & $40.9^{\mathrm{a}}$ & $18.6^{\mathrm{b}}$ & 5.3 \\
\hline
\end{tabular}

${ }^{a-c}$ Means with different superscript in the same row differ $(P<0.05)$

${ }^{1}$ Whole raw milk pasteurized before skimming.

${ }^{2}$ Actual yield $=(\mathrm{g}$ of curd/g of milk $) \times 100$.

${ }^{3}$ Corrected yield $=$ actual yield adjusted for the moisture of raw skim milk model cheese and TS content of the whey.

milk (before separation), buttermilk had no negative impact on lipid retention and reached a value similar to those observed for cheeses made from skim milk ingredients.

Retention of phospholipids in model cheeses was affected by the type of ingredient used in cheese milk and the ingredient thermal history $(P=0.0171)$. The maximum phospholipid retention (40.9\%) was observed for cheeses produced from pasteurized cream buttermilk, which was more than twice the retention observed in cheeses made with raw buttermilk, suggesting structural differences in MFGM complexes induced by heat treatments. High phospholipid retention might explain the poor contraction capacity observed for rennet gels produced with buttermilk from pasteurized cream (Table 3). Interestingly, pasteurization of whole milk (before separation) had no effect on phospholipid retention in cheeses made with buttermilk, and the retention coefficient was similar to that observed in cheeses made with raw buttermilk or skim milk ingredients.
Actual yields were higher for cheeses made with buttermilks than for those made with skim milk ingredients $(P=0.0012)$. This was related entirely to the higher moisture retention because yields adjusted for moisture and whey solids were significantly higher $(P=0.0026)$ in cheeses made with skim milk ingredients $(10.1 \%)$ than in those made with buttermilk ingredients $(9.1 \%)$. Lower retention for both proteins and lipids was responsible for the lower corrected yields observed in cheeses made with buttermilk ingredients.

Compositions of the wheys were also determined and are presented in Table 5 . The protein ingredients used in cheese milk and the thermal treatment applied during the preparation of ingredients had significant effects on protein $(P=0.0157)$, lipid $(P=0.0179)$, and phospholipid $(P=0.0420)$ concentrations in cheese whey. The higher protein concentration found in raw cream buttermilk whey was mainly attributable to the low retention of MFGM proteins, as shown in Figure 4 (lane 4). This is consistent with the higher phospholipid

Table 5. Average $(n=3)$ composition of wheys obtained from milk standardized with skim milk and buttermilk ingredients

\begin{tabular}{|c|c|c|c|c|c|c|c|}
\hline \multirow[b]{2}{*}{ Item } & \multicolumn{3}{|c|}{ Skim milks } & \multicolumn{3}{|c|}{ Buttermilks } & \multirow[b]{2}{*}{ SEM } \\
\hline & Raw & Pasteurized & $\begin{array}{c}\text { WM } \\
\text { pasteurized }^{1}\end{array}$ & $\begin{array}{l}\text { Raw } \\
\text { cream }\end{array}$ & $\begin{array}{c}\text { Pasteurized } \\
\text { cream }\end{array}$ & $\begin{array}{c}\text { WM } \\
\text { pasteurized }\end{array}$ & \\
\hline TS $(\%)$ & $6.79^{\mathrm{ab}}$ & $6.44^{\mathrm{b}}$ & $6.46^{\mathrm{b}}$ & $7.07^{\mathrm{a}}$ & $7.21^{\mathrm{a}}$ & $6.87^{\mathrm{ab}}$ & 0.18 \\
\hline True protein $(\%)$ & $0.751^{\mathrm{b}}$ & $0.746^{\mathrm{b}}$ & $0.664^{\mathrm{c}}$ & $0.914^{\mathrm{a}}$ & $0.763^{\mathrm{b}}$ & $0.768^{\mathrm{b}}$ & 0.021 \\
\hline Total lipids (\%) & $0.133^{\mathrm{c}}$ & $0.146^{\mathrm{c}}$ & $0.132^{\mathrm{c}}$ & $0.315^{\mathrm{b}}$ & $0.480^{\mathrm{a}}$ & $0.198^{b c}$ & 0.040 \\
\hline Phospholipids (\%) & $0.015^{\mathrm{c}}$ & $0.015^{\mathrm{c}}$ & $0.016^{\mathrm{c}}$ & $0.054^{\mathrm{a}}$ & $0.045^{\mathrm{b}}$ & $0.051^{\mathrm{a}}$ & 0.002 \\
\hline
\end{tabular}

${ }^{\mathrm{a}-\mathrm{c}}$ Means with different superscript in the same row differ $(P<0.05)$

${ }^{1}$ Whole raw milk pasteurized before skimming. 


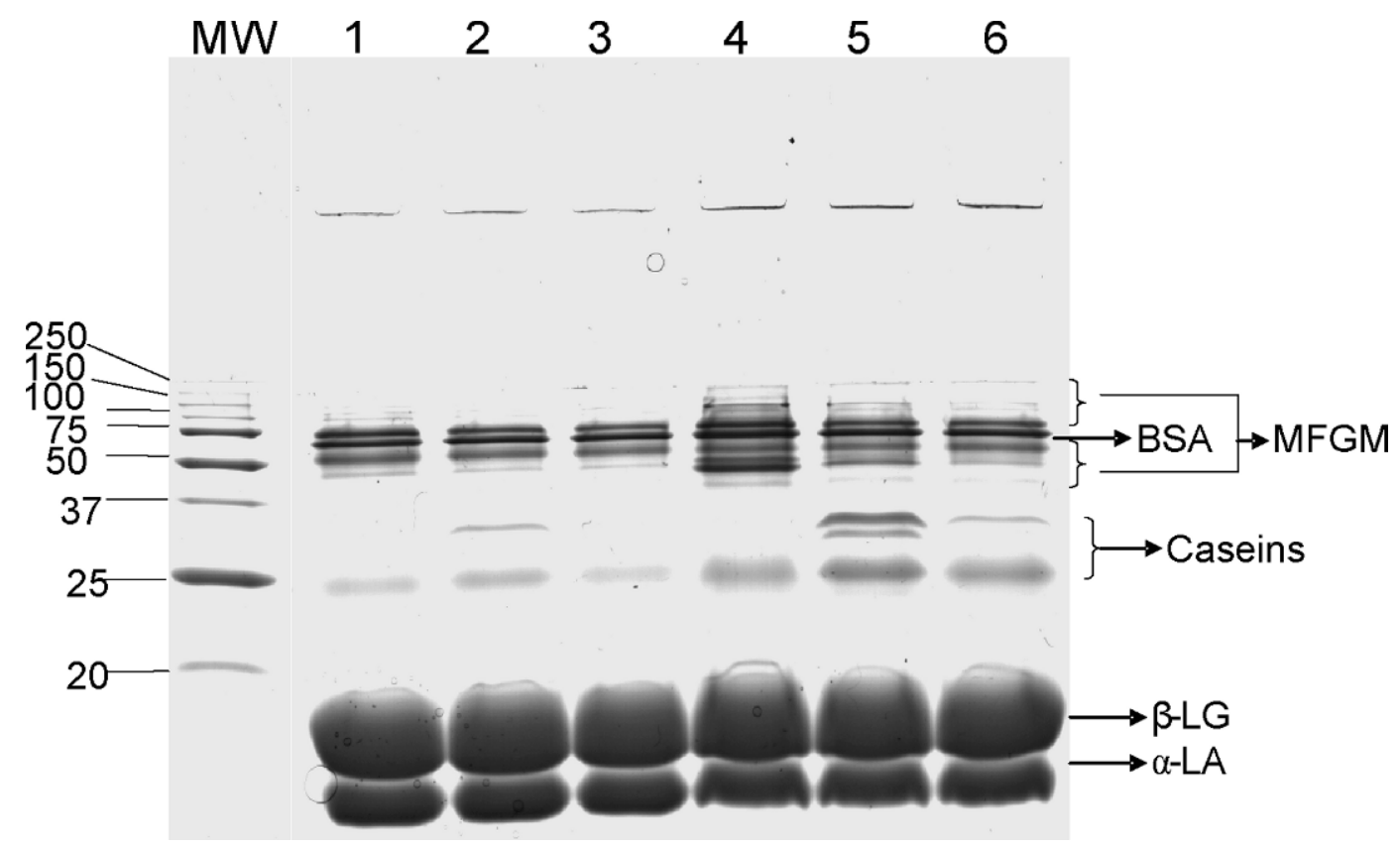

Figure 4. Sodium dodecyl sulfate-PAGE (15.0\% acrylamide) profile of whey from cheese milk standardized with (lane 1) raw skim milk, (lane 2) pasteurized skim milk, (lane 3) skim milk from milk pasteurized before separation, (lane 4) raw cream buttermilk, (lane 5) pasteurized cream buttermilk, and (lane 6) buttermilk from cream separated from pasteurized whole milk. Whey was diluted 1:3 with sample buffer. $\mathrm{MW}=$ molecular weight $(\mathrm{kDa}) ; \mathrm{MFGM}=$ milk fat globule membrane protein .

content, considering that phospholipids and MFGM proteins are linked together in MFGM particles. The amount of caseinomacropeptide was also measured in the resulting whey (not shown), but no differences were found among the 6 wheys, showing that ability of the rennet to cleave the $\kappa$-CN Phe $_{105}-$ Met $_{106}$ bond was not significantly affected by the presence of buttermilk or by the heat treatment.

\section{CONCLUSIONS}

This study confirmed that addition of buttermilk to cheese milk affects both rennet gel properties and model cheese manufacture. Many studies have reported that the presence of phospholipids or MFGM particles in buttermilk could be responsible for these altered properties. Although our results support this finding to a certain extent, they show that heat treatment of the cream is also a main reason for the buttermilk coagulation problems. However, the cream pasteurization process that is carried out before butter manufacture cannot be modified or altered for sanitary reasons. The potential use of buttermilk in cheese making might therefore be limited to the addition of minute amounts to cheese milk; this could minimize the problems observed in this work with 50\% of true protein replaced with buttermilk. Studies on the physicochemical properties of CN isolated from buttermilk as well as on the influence of mineral partition are already underway to gain a precise understanding of the effects observed in this study and to develop approaches for improving buttermilk utilization in cheese milk.

\section{ACKNOWLEDGMENTS}

This work was funded by the Le Fonds québécois de la recherche sur la nature et les technologies (FQRNT, Québec City, Québec, Canada)-Novalait Inc. (SainteFoy, Quebec, Canada)-Ministère de l'Agriculture, des Pêcheries et de l'Alimentation du Québec (MAPAQ, Québec City, Québec, Canada) research initiative and by the Natural Sciences and Engineering Research Council of Canada (NSERC, Ottawa, Ontario, Canada). The authors would like to thank Diane Montpetit (FRDC, St-Hyacinthe, Québec, Canada) for her help during scanning electron microscopy sample preparation and observation. The authors also wish to thank Gaétan Bélanger (FRDC) for his technical assistance during ingredient manufacture.

\section{REFERENCES}

AOAC. 2000. Official Methods of Analysis. 17th ed. AOAC Int., Arlington, VA.

Christie, W. W., R. C. Noble, and G. Davies. 1987. Phospholipids in dairy products. J. Soc. Dairy Technol. 40:10-12. 
Dalgleish, D. G., and J. M. Banks. 1991. The formation of complexes between serum proteins and fat globules during heating of whole milk. Milchwissenschaft 46:75-78.

Evers, J. M. 2004. The milkfat globule membrane-Compositional and structural changes post secretion by the mammary secretory cell. Int. Dairy J. 14:661-674.

Govindasamy-Lucey, S., T. Lin, J. J. Jaeggi, M. E. Johnson, and J. A. Lucey. 2006. Influence of condensed sweet cream buttermilk on the manufacture, yield, and functionality of pizza cheese. J. Dairy Sci. 89:454-467.

Govindasamy-Lucey, S., T. Lin, J. J. Jaeggi, C. J. Martinelli, M. E Johnson, and J. A. Lucey. 2007. Effect of type of concentrated sweet cream buttermilk on the manufacture, yield, and functionality of pizza cheese. J. Dairy Sci. 90:2675-2688.

Guinee, T. P., C. B. Gorry, D. J. O'Callaghan, B. T. O'Kennedy, N. O'Brien, and M. A. Fenelon. 1997. The effects of composition and some processing treatments on the rennet coagulation properties of milk. Int. J. Dairy Technol. 50:99-106.

Joshi, N. S., P. N. Thakar, and A. H. Jana. 1994. Utilization of butter milk in cheese making-A review. Ind. Food Packer 48:59-65.

Mistry, V. V., L. E. Metzger, and J. L. Maubois. 1996. Use of ultrafiltered sweet buttermilk in the manufacture of reduced fat Cheddar cheese. J. Dairy Sci. 79:1137-1145.

Morin, P., M. Britten, R. Jimenez-Flores, and Y. Pouliot. 2007a. Microfiltration of buttermilk and washed cream buttermilk for concentration of milk fat globule membrane components. J. Dairy Sci. 90:2132-2140.

Morin, P., R. Jimenez-Flores, and Y. Pouliot. 2007b. Effect of processing on the composition and microstructure of buttermilk and its milk fat globule membranes. Int. Dairy J. 10:1179-1187.

Morin, P., Y. Pouliot, and R. Jiménez-Flores. 2006. A comparative study of the fractionation of regular buttermilk and whey buttermilk by microfiltration. J. Food Eng. 77:521-528.

O'Connell, J. E., and P. F. Fox. 2000. Heat stability of buttermilk. J. Dairy Sci. 83:1728-1732.
Poduval, V. S., and V. V. Mistry. 1999. Manufacture of reduced fat Mozzarella cheese using ultrafiltered sweet buttermilk and homogenized cream. J. Dairy Sci. 82:1-9.

Raval, D. M., and V. V. Mistry. 1999. Application of ultrafiltered sweet buttermilk in the manufacture of reduced fat process cheese. J. Dairy Sci. 82:2334-2343.

Robitaille, G., H. J. Giroux, and M. Britten. 2004. Turbidity method to monitor the kinetics of rennet-induced coagulation of milk using a microplate reader. Milchwissenschaft 59:479-482.

Rombaut, R., J. v. Camp, and K. Dewettinck. 2006. Phospho- and sphingolipid distribution during processing of milk, butter and whey. Int. J. Food Sci. Technol. 41:435-443.

Statistics Canada. 2007. Butter production (Canada). Canadian Dairy Information Centre, http://www.dairyinfo.gc.ca/pdf/prod butter.pdf Accessed June 22, 2007.

Turcot, S., S. L. Turgeon, and D. St-Gelais. 2001. Effet de la concentration en phospholipides de babeurre dans le lait de fromagerie sur la production et la composition de fromage allégés de type cheddar. Lait 81:429-442.

USDA. 2006. 2006 Dairy Products Annual Summary. Natl. Agric. Statistics Serv. http://usda.mannlib.cornell.edu/usda/nass/ DairProd//2000s/2006/DairProd-12-01-2006.txt Accessed June $22,2007$.

Vasbinder, A. J., H. S. Rollema, and C. G. d. Kruif. 2003. Impaired rennetability of heated milk: Study of enzymatic hydrolysis and gelation kinetics. J. Dairy Sci. 86:1548-1555.

Walstra, P., J. T. M. Wouters, and T. J. Geurts. 2006. Dairy Science and Technology Handbook. 2nd ed. Taylor and Francis Group, Boca Raton, FL.

Wong, P. Y. Y., and D. D. Kitts. 2003. A comparison of the buttermilk solids functional properties to nonfat dried milk, soy protein isolate, dried egg white, and egg yolk powders. J. Dairy Sci. 86:746-754.

Ye, A., H. Singh, M. W. Taylor, and S. Anema. 2002. Characterization of protein components of natural and heat treated milk fat globule membranes. Int. Dairy J. 12:393-402. 